\title{
PECULIARITIES OF IMPLEMENTATION OF STAFFING MECHANISM OF LOCAL AUTHORITIES EFFECTIVE FUNCTIONING
}

Keywords: efficiency of functional processes, assessing the quality of staffing, local governments, ensuring efficient operation, qualimetry method.

\begin{abstract}
The essence of staffing of local governments is clarified in the work. It is substantiated that this is a system of principles, forms and methods of forming the necessary qualitative and quantitative composition of local governments, aimed at improving human resources and their effective use. The mechanism of staffing of local authorities effective functioning is offered, the feature of which is the inclusion of the processes of formation and realization. As a target orientation of the mechanism of staffing of local governments, their effective functioning is defined by achieving a certain goal to increase the level of life of the territorial community. The use of the qualimetric approach for construction of the optimum scenario of staffing of effective functioning of local governments is substantiated

The scheme of construction of qualimetric model of an estimation of quality of staffing of effective functioning of local governments is developed. It is determined that the quality of staffing of local governments is determined by analyzing the factors that have the greatest impact on of local governments staffing. As part of the study of the Merefa city united territorial community (Kharkiv region) the proposed qualimetric model was tested. Visualization of the level of quality of staffing of Merefa UTC in terms of functional processes allowed to determine that such functional processes as staff motivation and incentives, as well as staff development, professional development are the most important areas for improving the staffing process. The results of the sociological survey confirmed the important role of the level of competence of employees of executive bodies and the level of remuneration in the context of improving the efficiency of UTC.
\end{abstract}

1 Postgraduate Student at the Department of Public Administration and Regional Economy, Simon Kuznets Kharkov National University of Economics, nauka.zas@gmail. com, ORCID: 0000-0003-1028-1339. 
The proposed qualimetric model for assessing the quality of staffing allows not only to determine the effectiveness of local governments staffing, but also to identify those functional processes that require the most attention in terms of improving the functioning efficiency.

\section{INTRODUCTION}

The key factor in improving the efficiency of local governments in modern conditions is a special attitude to the staff. In order to obtain highly qualified specialists and create an incentive for them to work effectively, public organizations should form and implement a staffing mechanism. The formation and implementation of staffing mechanism in the sphere of local self-government is the basis for the creation of real human capital with knowledge, skills and abilities to effectively manage the life of territorial community. That is why the development and implementation of an appropriate mechanism for staffing the effective functioning of local governments is a timely issue.

Theoretical and applied aspects of staffing the process of effective functioning of local governments are presented in the works of such wellknown scientists as: Kh. Dejneha, V. Dziundziuk, N. Goncharuk, L. Khuzar, T. Kaghanovsjka, V. Olujko, O. Priieshkina, J. Pynes, A. Ritz, V. Schehortsova, N. Thom, V. Tkachuk, O. Vasylieva, V. Zolotarov and others. But the issue of staffing mechanism of the effective functioning of local governments is currently insufficiently studied, that determined the timeliness of the research topic.

Given the importance of applying new conceptual approaches to personnel management in local governments, the purpose of this article is to substantiate the peculiarities of the implementation of staffing mechanism of the effective functioning of local governments. To achieve this goal it is necessary to complete the following tasks: substantiation of the essence and structure of staffing mechanism of the effective functioning of local governments; identification and analysis of areas for ensuring the effective functioning of local governments; assessing the quality of staffing of local governments. 


\section{THE MECHANISM STRUCTURE}

Local self-government as a social institution of social development plays a key role in shaping the social and political activity of citizens, providing favorable living conditions for the population, improving its level and quality of life. At the same time, the formation of high-quality staffing of local self-government is one of the most important factors in socio-economic development of the country. The complexity of the task determines the need to attract the highly qualified management staff to the civil service, creating conditions for their professional development. But the most important is not only the level of professionalism of management, but also certain characteristics of their self-identification, compliance with ethical norms and specific moral requirements.

Financial insecurity of local budgets is one of the key factors that reduces the effectiveness of personnel policy of local governments. Thus, the results of a sociological survey of heads of local authorities revealed a high level of distraction of human and organizational resources from really important problems to ensure interaction with public authorities in conducting control and supervision measures. In addition, the high level of influence of regional elites on the activities of local authorities in the control and involvement of intergovernmental transfers of power exacerbates the destructive processes of staffing.

It should be noted that local governments, having their own economic base in the form of community property, form a budget by collecting taxes on it. However, it should not be forgotten that the scope of local self-government is still limited mainly to the territory of the settlement and solves a limited list of problems of its community life and activities for socioeconomic development, formation and use of both regional and district budgets, solving current and future problems of residents. Therefore, in the current conditions of decentralization of power there are still elements of the paternalistic model of local self-government, which stimulates the development of such qualities as a lack of initiative, focus on formal results and evaluation not of local residents but of superior bodies.

The number of factors limiting the effectiveness of local government staffing is caused by the insufficient training, retraining and advanced 
training programs for local governments. Thus, there are limited opportunities of improving the professional level of management. There is also a unified approach to training programs, which is not focused on territorial specifics and local issues. All this is complicated by the strengthening of the requirements of the state to the local governments.

It is also worth noting the limitations in the recruitment process, which is caused by the low interest of citizens in civil service. It is in front of rural settlements, heads of which are mostly concerned about the financial insufficiency of local budgets, the problems of motivation and material incentives become acute. In addition, because of unsatisfactory professional and personal characteristics of civil servants, the problem of shortage of professional staff in local governments is exacerbated.

Thus, the main factors limiting the formation of staffing of local authorities are: the high level of intensity of activity, which is explained by a significant number of control and supervision measures by public authorities; overstated workload; conflict risks in interactions with regional and local authorities, lack of local budgets.

In the course of the conducted sociological research the main directions of development of local self-government staffing were determined:

1. Improvement of the system of training, retraining and advanced training. The main areas of improving the effectiveness of training programs include: consideration of best practices of local government; organization of interaction between communities and local governments in order to exchange experiences, expand cooperation practices; concretization of programs taking into account the realities of a particular community and its socio-economic problems; individual approach, increasing the level of variability of curricula, taking into account the educational needs of students in a particular area.

2. Formation of ethical norms of modern local governments. It is the overcoming of corruption, the causes of which lie not only in economic and legal problems, but also in the professional deformation of government officials, that is the most significant vector of socio-cultural institutional changes in local self-government. Therefore, in the process of modernization of the civil service, special attention should be paid to the formation of corporate culture, its consolidation as the appropriate infor- 
mal requirements: corporate codes, ethical norms, etc. Today, part of the ethical norms of official conduct of local government officials is enshrined in law, but it is considered appropriate, along with the implementation of legislative regulation, to develop and consolidate in practice the code of ethics for local government officials.

3. Increasing the prestige of service in local governments. It is because of the lack of preferences and high social responsibility for the results of solving professional problems that the only motivator is an active civic position, the desire to make a significant contribution to the socio-economic development of community.

Thus, overcoming corruption, high level of responsibility, observance of ethical norms and values, information openness of local authorities, as well as priorities of public interests in the activities of government entities are the priority determinants of modernization of personnel policy in local self-governments and, accordingly, prerequisites functioning of local governments.

A key factor in improving the effective functioning of local governments in modern conditions is a special attitude to personnel. In order to get highly qualified specialists, to create an incentive for them to work effectively, organizations should form and implement a staffing mechanism. The formation of the mechanism of staffing in the field of local self-government is the basis for the creation of real human capital with knowledge, skills and abilities to effectively manage the life of territorial community. That is why the development of an appropriate mechanism for staffing the local governments is an urgent issue.

The complexity of the application of the concept of "mechanism" in public administration is due to the fact that it can be interpreted in several meanings, based on its etymology (translated from Greek; means a tool or structure) and used in various sciences for the analysis of interaction of certain elements during the implementation of a complex process. Thus, if we use the classification of all available mechanisms (including management), which is given in the work (Korotych, p. 20), they are divided into three very different types: mechanisms-tools, mechanisms-systems (representation of systems as mechanisms) and mechanisms-processes (sequence of certain transformations). 
Therefore, the essence of the mechanism of local governments staffing should be considered by assigning it to one of the types of management mechanisms. In particular, if the management mechanism is "a means of resolving the contradictions of a phenomenon or a process, the consistent implementation of actions based on fundamental principles, goal orientation, functional activity using appropriate management methods and is aimed at achieving a specific goal" (Odintsova, 2002, p. 12), then the mechanism of staffing as a certain type of management mechanism should be defined as a means of resolving the contradictions of the personnel management process for the effective functioning of the organization (in our case, the local government).

The staffing mechanism as a consistent implementation of actions should be based on an appropriate management technology, which should be based on the principles of parity, objectivity, transparency, systematics, complexity, consistency of interests, management efficiency, priority and incentives for staff. As a target orientation of staffing mechanism of the local self-government should be its effective functioning by means of achieving a certain goal to increase the level of life of the territorial community.

The implementation of this mechanism is based on the interaction of management methods (economic, administrative and socio-psychological), management functions (planning, organization, control, coordination, motivation), appropriate support (legal, regulatory, analytical, informational, organizational, motivational), actions , operations, procedures that are inherent in the staffing process and through the periodic monitoring and consideration of external factors (political, legislative, socio-cultural, economic, technical, technological, socio-psychological, managerial and cultural factors) and internal environment (goals and strategy, personnel policy, marketing activities, professional and qualification factors, organizational culture and structure and socio-psychological climate in the team) .

In order to implement measures to improve personnel management in local governments, there is a need to use the appropriate management methods. The basis for the implementation of economic methods is a material reward for productive work, where the key form is wages. The 
timeliness of salary payments, its size and nature are inextricably linked with the functional processes of personnel management in a public organization. Socio-psychological methods include ways to influence the spiritual and social needs of a man, specific methods of action in the process of formation and development of a team. They differ in their motivational characteristics that determine the direction of actions. Administrative methods are based on the effective use of influence, power and leadership. With the help of such forms of manifestation of administrative methods as: obligatory prescription (order, prohibition), contractual methods (consultation, permission of compromise), recommendations, wishes (advice, explanation, proposal), tasks of stabilizing and administrative character and also the tasks of organizing the work of teams are performed. Note that the use of administrative methods involves not only disciplinary action against performers, but also a suitable form of remuneration, which is implemented within the scope of economic methods.

According to J. Pynes, public and non-profit organizations are somewhat labor-intensive, as their activities require a sufficient number of people, and their efficiency depends on the knowledge, skills, abilities and other characteristics of staff. To be successful, organizations need to develop progressive methods of personnel management. At the same time, understanding the legal environment that affects personnel management, social and cultural changes taking place in society, the change of generations that occurs in modern working conditions, as well as educational trends are extremely important.

An important component of the proposed mechanism is the existing functional processes. Thus, J. Pynes defines the following processes of personnel management in public organizations: analysis of personnel, selection of personnel, performance management (including motivation, development of an evaluation program, certification), training and development, labor relations management (Pynes, 2009). N. Tom and A. Rits have another point of view, according to which the personnel management system in the public sector includes: recruitment, personnel selection, staff placement, staff development, staff dismissal (Tom, 2004).

Given the existing scientific achievements of scientists (Dejneha, 2011; Pynes, 2009; Tom, 2004), we note that there are no special differences from 
the functional processes of personnel management in the private sector, so we define the main and important processes of personnel management in public organizations as follows: selection of personnel; staff evaluation, staff motivation, staff development, staff control.

Recently, personnel processes in public organizations are chaotic and sometimes unfounded. This is due to a certain subjectivity in the recruitment, selection and promotion of staff, which arises as a result of political involvement or monopoly and individual decision. Therefore, in order to positively resolve this situation, it is necessary to form an effective mechanism for staff selection, while using modern technology of personnel management. In addition, according to V. Schehortsova (Schehortsova, 2011), when hiring and selecting staff in public organizations, it is important to take into account the nature of an individual, to determine the type of his temperament. This will allow to predict the behavior of staff during the work, identify their motives and incentives to work, and so on.

It should be emphasized that evaluating staff and determining the effectiveness of their work in a public organization is rather a difficult task due to the need to take into account the influence of many factors. A comprehensive approach is needed to assess staff, which will combine the methods of statistical analysis with the methods used in sociological research. This will identify the existing labor potential and develop specific recommendations for the use of specific technologies of personnel management. According to W. Landsman, the lack of effective methods of evaluating the work of civil servants is one of the main reasons for their lack of interest in the results of their own activities, the emergence of corruption at various levels.

Stability of staff in public organizations is also achieved by improving its professional level through training, retraining and self-development. High-quality staff work requires thorough professional knowledge, skills and abilities, a high level of education, the presence of high moral principles and attitudes. In turn, the inconsistency of the processes of professional development of staff in public organizations, the lack of an effective mechanism for promotion confirm the disinterest of staff in continuous professional self-improvement. Therefore, the following requirements must be taken into account when working with the staff [Goncharuk, 
2012; Olujko, 2008; Dziundziuk, 2009]: respect for the individuality and integrity of each person by encouraging high productivity; creating and maintaining an atmosphere of search, creativity, activity in the implementation of managerial decisions; creating conditions for the realization of human rights; responsibility for training, retraining and advanced training of the staff; encouraging cases of taking responsibility in difficult situations; creating conditions for the development of creative abilities; introduction of a fair system of remuneration, promotion; complex examination of activity: both on process, and on result; maintaining responsibility for the quality of work and the fate of the organization.

One of the most effective tools to increase the effectiveness of professional activities of staff in public organizations is incentives. After all, these are interests, motives, incentives that are the driving force of any activity. But staff motivation in public organizations is somewhat different from the incentive process in private sector organizations. Yes, it is impossible to stimulate the staff "as a percentage" of income for a qualitative work. The staff of a public organization should be motivated to work diligently, to serve the community and the state, to fully fulfill the obligation to provide citizens with the full range of services. In this context, a significant role is also played by personal, moral and ethical traits of an employee: his empathy, integrity, openness, honesty, patriotism, sense of duty, ability to cooperate, desire for self-improvement, etc. (Huzar, 2013).

It should be noted that the mechanism of the effective staffing of local governments in a decentralized environment has a significant impact on ensuring the competitiveness of regions and the formation of their competitive advantages. Despite the significant number of scientific developments of scientists and their accumulated experience in improving the forms and methods of personnel management, most government organizations (institutions) due to lack of highly qualified management staff and outdated concept of personnel policy are unable to respond quickly to changes in the labor market, introduction of modern technologies of personnel work, new requirements to mobile reorientation of the available intellectual potential, etc. 


\section{DIRECTIONS FOR ENSURING THE EFFECTIVE FUNCTIONING OF LOCAL GOVERNMENTS}

The main condition for increasing the competitiveness of a region is not just the construction of a staffing mechanism of local authorities effective functioning but the use on the ground of the proposed areas that can provide real socio-economic return. Due to this, the issues of formation and implementation of staffing mechanism of local authorities effective functioning are most relevant in the study. The directions of the process of ensuring the effective functioning of local governments in the implementation of the mechanism, based on the principles of a functional approach with the separation of motivational, organizational and informational components, are presented in Fig. 1.

Ensuring the efficiency of the declared components is due to the identification of those business processes of personnel management that have the greatest impact on the efficiency of local governments.

The proposed components are transformed into appropriate areas to improve staffing mechanism of local authorities effective functioning:

the organizational component is provided by means of the optimum scenario of staffing which construction is based on use of the scenario approach;

the information component is provided by the automation of business processes, determination of labor productivity, transparent system of planning and budgeting, and also introduction of the intellectual centers for an exchange;

the motivational component is provided by building maps of selfdevelopment, identification and justification of motivators and demotivators of effective functioning of local governments.

\section{ASSESSING THE QUALITY OF STAFFING}

To implement the mechanism, the use of a qualimetric approach to build an optimal staffing scenario for the effective functioning of local governments is proposed. The application of the method of qualimetry 


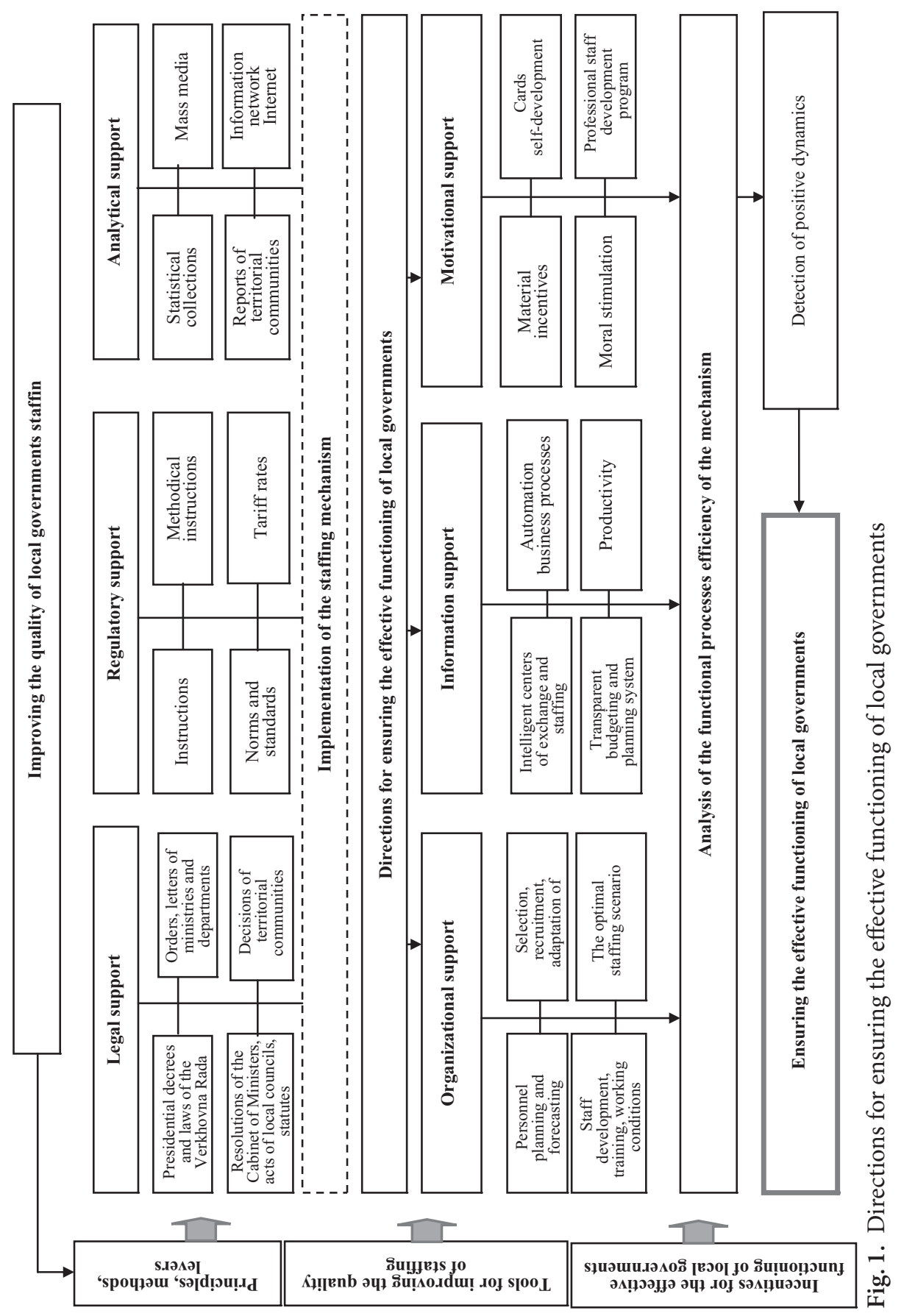


will determine the quality of staffing, which will ultimately help to justify the optimal scenario.

A thorough analysis of the features of the application of methods used for quality assessment (Fig. 2), including methods of fuzzy set theory, qualimetry methods and the method of analysis of Saati hierarchies, confirms the lack of a unified conceptual approach to evaluation.

Method of fuzzy set
theory

Fig. 2. Features of quality assessment methods

But given the sufficient complexity of the procedure of analysis of Saati hierarchies and a certain limitation of traditional mathematical methods for data analysis, the use of a qualimetric approach is justified. In modern conditions of development of world economic science for quality assessment this method is the most widespread, however in our country insufficient attention is paid from the point of view of quality assessment of processes of staffing of personnel administrative activity.

When evaluating the qualitative component of the result of personnel management using a qualimetric approach, it is important to adhere to the following principles (Varzhapetjan, 2005): representation of simple components of the factor-criterion model in the form of a hierarchical 
structure; defined quality standard for comparison of achieved results; the ability to compare indicators in different units; determining the importance of each factor in terms of priority; comprehensive quantitative assessment of quality is presented as a function of relative indicators and weights. The scheme of forming a qualimetric model for assessing the quality of staffing the effective functioning of local governments is presented in Fig. 3.

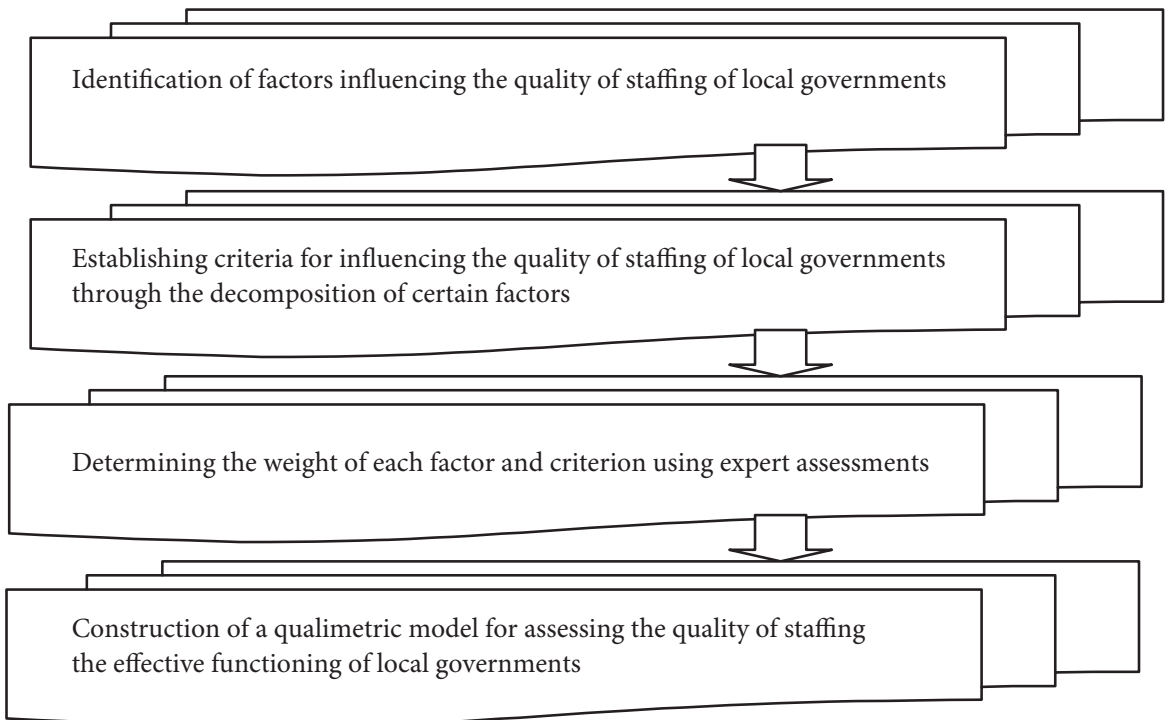

Fig. 3. The scheme of construction of a qualimetric model for assessing the quality of staffing the effective functioning of local governments

It should be noted that in order to determine the weight of each factor and criterion, expert evaluation which provides: formulation of the purpose of expert evaluation; formation of a group of experts; determination of a set of priority criteria; examination; processing of examination results; analysis and results of the survey; determining the level of agreement of experts' opinions; substantiation of the relevant conclusions on the significance of each criterion is used. The concordance coefficient is used to assess the degree of consistency of experts' opinions. 
Therefore, to determine the level of ensuring the effectiveness of personnel management, you can use a system of indicators to evaluate each business process. The basis of the formation of staffing mechanism of local authorities effective functioning, is a functional approach, according to which the main functional processes in personnel management were considered (Table 2).

It should be noted that the structure of the qualimetric model is as follows: factors for which functional processes are conditionally accepted; criteria for which the requirements for the process in a certain direction are conditionally accepted; weight of factors and criteria (significance, priority); degree of compliance. In this case, the coefficient of conformity is measured as follows: $\mathrm{B}=1$ - full compliance with the requirements (yes); B $=0.75$ - partial compliance (more so than not); $\mathrm{B}=0.50$ - balanced compliance with the requirements (both yes and no); $\mathrm{B}=0.25-$ partially negative compliance with the requirements (no more than yes); $\mathrm{B}=0$ - complete non-compliance with the requirements (no). The higher the overall assessment of the presented factors, the lower the need for changes in personnel management.

The approbation of the proposed qualimetric model was carried out within the framework of the study of town of Merefa united territorial community (Kharkiv region). As for the obtained overall assessment of the quality of united territorial communities (UTC) staffing, it amounted to 0.675. This indicates a moderate need to improve such functional processes in Merefa UTC, as motivation and stimulation of the staff, as well as staff development, improving their professional skills. Visualization of the level of quality of staffing of Merefa UTC in terms of functional processes allowed to determine that such functional processes as staff motivation and incentives, as well as staff development, where professional development are the most important areas for improving the staffing process.

In addition, a sociological survey conducted among the united territorial communities of Kharkiv region identified factors that affect the effectiveness of their activities. The results of the survey confirmed the important role of the level of competence of employees of executive bodies and the level of remuneration in the context of improving the efficiency of UTC. 
Table 1. Qualimetric model for assessing the quality of staffing mechanism of local authorities effective functioning

\begin{tabular}{|c|c|c|c|c|}
\hline $\begin{array}{c}\text { Functional } \\
\text { process } \\
(\text { factor }-\mathrm{f})\end{array}$ & \begin{tabular}{|c|} 
Weight \\
of the \\
factor \\
$-\mathrm{vf}$
\end{tabular} & Criteria $-\mathrm{k}$ & $\begin{array}{c}\text { Evaluation } \\
\text { of criteria } \\
\text { - OK }\end{array}$ & $\begin{array}{c}\text { Evaluation } \\
\text { of factors } \\
\text { - OF }\end{array}$ \\
\hline 1 & 2 & 3 & 6 & 7 \\
\hline \multirow{3}{*}{$\begin{array}{l}\text { Analysis of } \\
\text { personnel } \\
\text { processes and } \\
\text { their plan- } \\
\text { ning } \mathrm{f}_{1}\end{array}$} & \multirow[t]{3}{*}{$\mathbf{v f}_{1}$} & $\begin{array}{l}\text { 1.1. The process of analysis of per- } \\
\text { sonnel policy of personnel manage- } \\
\text { ment with the existing strategy }\left(\mathrm{K}_{1}\right)\end{array}$ & $\mathrm{BK}_{1} \mathrm{xB}_{1}$ & \multirow[t]{3}{*}{ 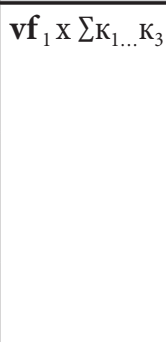 } \\
\hline & & $\begin{array}{l}\text { 1.2. The process of developing and } \\
\text { adjusting the personnel management } \\
\text { policy }\left(\mathrm{K}_{2}\right)\end{array}$ & $\mathrm{BK}_{2} \mathrm{xB}_{2}$ & \\
\hline & & $\begin{array}{l}\text { 1.3. The process of selecting a per- } \\
\text { sonnel management strategy }\left(\mathrm{K}_{3}\right)\end{array}$ & $\mathrm{BK}_{3} \mathrm{xB}_{3}$ & \\
\hline \multirow{3}{*}{$\begin{array}{l}\text { Selection } \\
\text { and selection } \\
\text { of personnel } \\
\mathrm{f}_{2}\end{array}$} & \multirow[t]{3}{*}{$\mathbf{v f}_{2}$} & $\begin{array}{l}\text { 2.1. Determining the need for staff } \\
\text { from internal and external sources } \\
\left(\mathrm{K}_{4}\right)\end{array}$ & $\mathrm{BK}_{4} \mathrm{xB}_{4}$ & \multirow[t]{3}{*}{$\mathbf{v f}_{2} \times \sum \mathrm{K}_{4} \ldots \mathrm{K}_{6}$} \\
\hline & & $\begin{array}{l}\text { 2.2. An integrated approach to deter- } \\
\text { mining the need for staff }\left(\mathrm{K}_{5}\right)\end{array}$ & $\mathrm{BK}_{5} \mathrm{xB}_{5}$ & \\
\hline & & $\begin{array}{l}\text { 2.3. Determining the target staffing } \\
\text { needs based on the organization of } \\
\text { jobs }\left(\mathrm{K}_{6}\right)\end{array}$ & $\mathrm{BK}_{6} \mathrm{xB}_{6}$ & \\
\hline \multirow{2}{*}{$\begin{array}{l}\text { Staff adapta- } \\
\text { tion } \\
\mathbf{f}_{3}\end{array}$} & \multirow[t]{2}{*}{$\mathbf{v f _ { 3 }}$} & 3.1. Personnel adaptation process $\left(\mathrm{K}_{7}\right)$ & $\mathbf{B K}_{7} \mathbf{x B}_{7}$ & \multirow[t]{2}{*}{$\mathbf{v f}_{3} \times \sum \kappa_{7, \ldots} \kappa_{8}$} \\
\hline & & $\begin{array}{l}\text { 3.2. The process of personnel certifi- } \\
\text { cation }\left(\mathrm{\kappa}_{8}\right)\end{array}$ & $\mathrm{BK}_{8} \mathrm{xB}_{8}$ & \\
\hline \multirow{2}{*}{$\begin{array}{l}\text { Evaluation } \\
\text { and control } \\
\text { of staff ac- } \\
\text { tions } \mathrm{f}_{4}\end{array}$} & \multirow[t]{2}{*}{$\mathbf{v f _ { 4 }}$} & 4.1. Personnel evaluation process $\left(\kappa_{9}\right)$ & $\mathrm{BK}_{9} \mathrm{xB}_{9}$ & \multirow[t]{2}{*}{$\mathbf{v f}_{4} \times \sum \mathrm{K}_{9 . \ldots} \mathrm{K}_{1}$} \\
\hline & & $\begin{array}{l}\text { 4.2. The process of current accoun- } \\
\text { ting of personnel and workplace mo- } \\
\text { nitoring }\left(\mathrm{K}_{10}\right)\end{array}$ & $\mathrm{BK}_{10} \mathrm{xB}_{10}$ & \\
\hline \multirow{3}{*}{$\begin{array}{l}\text { Motivation } \\
\text { and stimula- } \\
\text { tion of staff } \\
\mathbf{f}_{5}\end{array}$} & \multirow[t]{3}{*}{$\mathbf{v \mathbf { f } _ { 5 }}$} & $\begin{array}{l}\text { 5.1. The process of influencing the } \\
\text { material factors of staff motivation } \\
\left(\kappa_{11}\right)\end{array}$ & $\mathrm{BK}_{11} \mathrm{xB}_{11}$ & \multirow[t]{3}{*}{$\begin{array}{l}\mathbf{v f}_{5} \times \sum \mathrm{K}_{11 \ldots} \\
\mathrm{K}_{13}\end{array}$} \\
\hline & & $\begin{array}{l}\text { 5.2. The process of influencing intan- } \\
\text { gible factors of staff motivation }\left(\mathrm{K}_{12}\right)\end{array}$ & $\mathrm{BK}_{12} \mathrm{xB}_{12}$ & \\
\hline & & $\begin{array}{l}\text { 5.3. The process of development of } \\
\text { organizational culture }\left(\mathrm{K}_{13}\right)\end{array}$ & $\mathbf{B K}_{13} \mathrm{xB}_{13}$ & \\
\hline
\end{tabular}




\begin{tabular}{|c|c|c|c|c|}
\hline $\begin{array}{l}\text { Functional } \\
\text { process } \\
(\text { factor }-\mathrm{f})\end{array}$ & $\begin{array}{l}\text { Weight } \\
\text { of the } \\
\text { factor } \\
\text { - vf }\end{array}$ & Criteria - k & $\begin{array}{l}\text { Evaluation } \\
\text { of criteria } \\
-\mathrm{OK}\end{array}$ & $\begin{array}{l}\text { Evaluation } \\
\text { of factors } \\
- \text { OF }\end{array}$ \\
\hline 1 & 2 & 3 & 6 & 7 \\
\hline \multirow{3}{*}{$\begin{array}{l}\text { Staff deve- } \\
\text { lopment, } \\
\text { raising its } \\
\text { professional } \\
\text { qualification } \\
\text { level }_{6}\end{array}$} & \multirow[t]{3}{*}{$\mathbf{v f _ { 6 }}$} & $\begin{array}{l}\text { 6.1. The process of training and retra- } \\
\text { ining of staff }\left(\kappa_{14}\right)\end{array}$ & $\mathrm{BK}_{14} \mathrm{xB}_{14}$ & \multirow[t]{3}{*}{$\begin{array}{l}\mathbf{v f _ { 6 }} \times \sum \mathrm{K}_{14 \ldots} \\
\mathrm{K}_{16}\end{array}$} \\
\hline & & $\begin{array}{l}\text { 6.2. The process of general staff deve- } \\
\text { lopment }\left(\kappa_{15}\right)\end{array}$ & $\mathbf{B K}_{15} \times \mathbf{B}_{15}$ & \\
\hline & & $\begin{array}{l}\text { 6.3. The level of socio-psychological } \\
\text { climate }\left(\kappa_{16}\right)\end{array}$ & $\mathrm{BK}_{16} \mathrm{xB}_{16}$ & \\
\hline \multirow{3}{*}{$\begin{array}{l}\text { Labor rela- } \\
\text { tions, quality } \\
\text { of life, wor- } \\
\text { king condi- } \\
\text { tions } \mathrm{f}_{7}\end{array}$} & \multirow[t]{3}{*}{$\mathbf{v f _ { 7 }}$} & $\begin{array}{l}\text { 7.1. The process of reducing conflict } \\
\text { and ensuring a comfortable socio- } \\
\text {-psychological climate }\left(\mathrm{K}_{17}\right)\end{array}$ & $\mathbf{B K}_{17} \mathbf{x B}_{17}$ & \multirow[t]{3}{*}{$\begin{array}{l}\mathbf{B} \boldsymbol{\phi}_{7} \times \sum \kappa_{17 \ldots} \\
\kappa_{19}\end{array}$} \\
\hline & & $\begin{array}{l}\text { 7.2. The process of managing the } \\
\text { current safety of personnel }\left(\kappa_{18}\right)\end{array}$ & $\mathrm{BK}_{18} \mathrm{xB}_{18}$ & \\
\hline & & $\begin{array}{l}\text { 7.3. The process of creating working } \\
\text { conditions and monitoring the safety } \\
\text { of personnel }\left(\kappa_{19}\right)\end{array}$ & $\mathbf{B K}_{19} \mathbf{x B}_{19}$ & \\
\hline
\end{tabular}

Designation: Вк - weight of criteria; B - coefficient of conformity

\section{CONCLUSIONS}

Thus, it should be noted that the processes of European integration create the conditions for decentralization of public administration, participation of citizens in local government decision-making, more "transparent" provision of services. But with the strengthening of close integration processes, there is a need for more effective work of local governments. Therefore, the essence of staffing of local governments is clarified in the work. It is substantiated that this is a system of principles, forms and methods of forming the necessary qualitative and quantitative composition of local governments, aimed at improving human resources and their effective use. The mechanism of staffing of local authorities effective functioning is offered, the feature of which is the inclusion of the processes of formation and realization. As a target orientation of the 
mechanism of staffing of local governments, their effective functioning is defined by achieving a certain goal to increase the level of life of the territorial community. It is determined that the quality of staffing of local governments is determined by analyzing the factors that have the greatest impact on of local governments staffing.

\section{BIBLIOGRAPHY:}

Dejneha, Kh.M. (2011). Personnel Management public service, international experience and terms of implementation in Ukraine, Ekonomika ta derzhava, vol. 1, pp. 151-153. Dziundziuk, V.B. (2009). Features making strategies in public organizations, Derzhavne budivnytstvo, [Online], vol. 1, retrieved from: http://nbuv.gov.ua/UJRN/DeBu_2009_1_48 Goncharuk, N.T. (2012), Upravlinnia kerivnym personalom u sferi derzhavnoi sluzhby Ukrainy: teoriia ta praktyka [Management senior staff in the civil service of Ukraine: Theory and Practice], Donetsk: DRIDU NADU. [in Ukrainian]

Huzar, L. (2013). Motivational factors increasing the efficiency of public servants in Ukraine, Efektyvnist' derzhavnoho upravlinnia, vol. 35, pp. 196-202.

Kaghanovsjka, T. Je. (2010). Kadrove zabezpechennja derzhavnogho upravlinnja v Ukrajini [Personnel support of public administration in Ukraine]. Kharkiv: KhNU imeni V. N. Karazina. [in Ukrainian]

Odinczova, G. S., Mostovy`j, G. I. et al. (2002). Derzhavne upravlinnya i menedzhment [Public administration and management]. Kharkiv: XarRI UADU. [in Ukrainian] Olujko, V.M. (2008). Derzhavna kadrova polityka: teoretyko-metodolohichne zabezpechennia [State personnel policy: theoretical and methodological support]. Kyiv: NADU. [in Ukrainian]

Priieshkina, O. V. (2015). Kadrove zabezpechennia orhaniv mistsevoho samovriaduvannia: aktualni problemy [Staffing of local governments: current issues]. Proceedings of the $70^{\text {th }}$ scientific conference of the academic staff of the Faculty of Law and Economics of Odesa I.I. Mechnikov National University devoted to the $150^{\text {th }}$ anniversary of Odesa I.I. Mechnikov National University (Ukraine, Odessa, November 25-27, 2015). Downloaded from: http://dspace.onu.edu.ua:8080/handle/123456789/7850

Priadko, V. V. \& Piren, M. I. (2015). Kadrova polityka - naivazhlyvisha derzhavotvorcha tsinnist dlia realizatsii reform $\mathrm{v}$ Ukraini [Personnel policy - the most important state-building value for the implementation of reforms in Ukraine]. Visnyk NADU, no. 3., pp. 78-83.

Pynes, J. (2009). Human resources management for public and nonprofit organizations: a strategic approach, 3rd ed. Jossey Bass: San Francisco, USA. 
Schehortsova, V. M. (2011). Personnel management in government: the psychological aspect. Derzhavne budivnytstvo [Online], vol. 2. Downloaded from: http://nbuv.gov. ua/UJRN/DeBu_2011_2_32

Thom, N. and Ritz, A. (2004). Public Management. Innovative public-sector management warp, Lietuvos teisès universiteto Leidybos centras, Vilnius, Lithuania.

Tkachuk, V. A. (2013). Problemy ocinjuvannja jakosti ta efektyvnosti dijaljnosti orghaniv miscevoji vlady (zarubizhnyj dosvid) [Problems of assessing the quality and efficiency of local authorities (foreign experience)]. Problemy innovacijno-investycijnogho rozvytku, no. 5, pp. 50-54.

Varzhapetjan, A.G. (2005). Kvalimetrija [Qualimetry], SPb.: GUAP [in Russian].

Vasyliev,a O. I. (2011). Kadrove zabezpechennia orhaniv mistsevoi vlady [Staffing of local authorities]. Investytsii: praktyka ta dosvid, no. 6. pp. 57-60.

Vytko, T. (2010). Foreign experience of public authorities frames. Derzhavne upravlinnia ta mistseve samovriaduvannia, vol. 1, pp. 260-269.

Zolotar'ov, V. F. (2014). Sutnist kadrovoho zabezpechennia orhaniv mistsevoho samovriaduvannia [The essence of staffing local government]. Derzhavne budivnytstvo, no. 2 . Downloaded from: http://nbuv.gov.ua/UJRN/DeBu_2014_2_21 